This is an electronic reprint of the original article. This reprint may differ from the original in pagination and typographic detail.

\author{
Author(s): Suuronen, Anna; Lensu, Anssi; Kuitunen, Markku; Andrade-Alvear, Rodrigo; Celis, \\ Natalia Guajardo; Miranda, Marcelo; Perez, Marcelo; Kukkonen, Jussi
}

Title: $\quad$ Optimization of photovoltaic solar power plant locations in northern Chile

Year: $\quad 2017$

Version:

Please cite the original version:

Suuronen, A., Lensu, A., Kuitunen, M., Andrade-Alvear, R., Celis, N. G., Miranda, M., Perez, M., \& Kukkonen, J. (2017). Optimization of photovoltaic solar power plant locations in northern Chile. Environmental Earth Sciences, 76(24), 824. https://doi.org/10.1007/s12665-017-7170-z

All material supplied via JYX is protected by copyright and other intellectual property rights, and duplication or sale of all or part of any of the repository collections is not permitted, except that material may be duplicated by you for your research use or educational purposes in electronic or print form. You must obtain permission for any other use. Electronic or print copies may not be offered, whether for sale or otherwise to anyone who is not an authorised user. 


\title{
Optimization of photovoltaic solar power plant locations in northern Chile
}

\author{
Anna Suuronen ${ }^{\mathrm{a}, *}$, Anssi Lensu ${ }^{\mathrm{a}}$, Markku Kuitunen ${ }^{\mathrm{a}}$, Rodrigo Andrade-Alvear ${ }^{\mathrm{b}}$, Natalia Guajardo Celis ${ }^{\mathrm{c}}$, \\ Marcelo Miranda ${ }^{\mathrm{c}}$, Marcelo Perez ${ }^{\mathrm{d}}$, Jussi V.K. Kukkonen ${ }^{\mathrm{a}}$
}

${ }^{\text {a} U n i v e r s i t y ~ o f ~ J y v a s k y l a, ~ D e p a r t m e n t ~ o f ~ B i o l o g i c a l ~ a n d ~ E n v i r o n m e n t a l ~ S c i e n c e, ~ S e c t i o n ~ o f ~ E n v i r o n m e n t a l ~}$

Science and Technology, P.O. Box 35, FI-40014 University of Jyvaskyla, Finland.

*Corresponding author Tel. +358 (0)14 260 1211, Fax: +358 (0)14 617 239, E-mail address:

annamsuuronen@gmail.com,

'Department of Zoology, Faculty of Natural Sciences and Oceanographics, University of Concepción,

Concepción, Chile.

'Department of Ecosystems and Environment, Pontificia Universidad Católica de Chile, Santiago, Chile.

${ }^{\mathrm{d}}$ Department of Electronics, Federico Santa María Technical University, Valparaíso, Chile.

\section{ABSTRACT}

The optimization of photovoltaic (PV) solar power plants location in Atacama Desert, Chile, is presented in this study. The study considers three objectives: 1) Find sites with the highest solar energy potential, 2) determine sites with the least impact on the environment, and 3) locate the areas which produce small social impact. To solve this task, multi-criteria decision analyzes (MCDA) such as analytical hierarchy process (AHP) and ordered weighted averaging (OWA) were applied in a GIS environment. In addition, survey results of social impacts were analyzed and included into the decision-making process, including landscape values. The most suitable sites for solar energy projects were found near roads and power lines throughout the study area. Large suitable areas were found also from central valley from Arica and Parinacota to the north edge of Atacama region. In Atacama region, most suitable sites were found in the Andes. On the contrary, Andes were also found to have high environmental values and scenically valuable landscapes. Moderate and low suitability were found on the coast, especially in Atacama region. Factors such as slope and distance to power lines and roads influenced largely the sensitivity analysis. Area of high suitability increased by $15 \%$ when distance to roads was excluded and $18 \%$ when distance to power lines or slope was removed. MCDA-GIS method was found to be useful and applicable to the optimization of solar power plant locations in northern Chile.

KEYWORDS: AHP_OWA -method, GIS, Multi-criteria decision analyze, Northern Chile, Photovoltaic solar power plants, Site selection 
Fossil fuels consumption has been increasing (Yonca Aydin et al. 2010) despite of the Paris Agreement to the

United Nations framework convention on climate change (United Nations 2015). Maintaining the economic development without neglecting environmental issues has turned the focus of policies of several countries towards renewable energy systems (RES) (Yonca Aydin et al. 2010). Solar energy systems are air pollution free during their maintenance phase, and therefore, considered environmentally friendly forms to produce energy (Wang and Qiu 2009). Solar energy is an advantageous option especially in arid areas where solar energy potential is high (Moriarty and Honnery 2012). Phovoltaic (PV) solar power plants, especially so-called thin film panels, have gained popularity because the solar panels have recently become more affordable (Hosenuzzaman et al. 2015).

Sustainable energy as a part of sustainable development is defined as equality of providing energy to all people and protection of environment to the next generations (Omer 2008). Renewable energies have been approved to be sustainable. Nevertheless, there are still considerations related to the RES installation (Nguyen 2007; Yonca Aydin et al. 2010). RES have positive impacts such as mitigation of the effects of greenhouse gases (Alsema 2000; Shafiee and Topal 2009). Relevant negative environmental impacts of solar power plants are caused by the construction phase of panel areas when soil is removed and altered (Tsoutsos et al. 2005). Removal of the soil destroys biological crust (Johansen and Clair 1986) and local flora and fauna (Wu et al. 2014). In addition, maintenance phase of PV plants has ecological impacts such as habitat fragmentation, breaking of ecological corridors, and loss of habitats. Panels also alter microclimate that causes biota conditions to change, resulting in, for example, changes in species' abundances and/or compositions (Tsoutsos et al. 2005; Wu et al. 2014; Suuronen et al. 2017). Therefore, environmental and ecological impacts should be considered when planning PV plant projects.

Studies of biodiversity loss, climate change, etc. have proved that environmental problems cannot be solved only as environmental problems, but also social studies related to them are needed (Binder et al. 2013). Literature reveals that environmental and economic factors of landscape have been analyzed more profoundly than social factors (Parsons and Daniel 2002; Tolli et al. 2016). Tools to measure social factors are not fast and effective because opinions are hard to measure and analyze (Daniel 2001; Sevenant and Antrop 2009). Therefore, social factors are often left with less attention (Olson-Hazbourn et al. 2016; Tolli et al. 2016). Literature identifies that the most important social impacts of solar energy are public acceptance, job creation, and social benefits such as 
plants is not only due to environmental benefits, but also related to economical beliefs and landscape impacts (Olson-Hazbourn et al. 2016).

Optimal site selection for PV solar plants requires multidisciplinary data. Nevertheless, not all disciplines support the selection of the same geographical sites (Malczewski 1999). For example, energy potential of some area can be high but the area can possess high biodiversity value, and therefore, it is not suitable for PV solar plant projects. While working with spatial information, geographic information systems (GIS), such as ArcGIS (ESRI, Redlands, CA) are commonly used (Carver 1991; Arán Carrión et al. 2008; Yonca Aydin et al. 2010; Charabi and Gastli 2011; Uyan 2013; Watson and Hudson 2015; among others). Complex databases need to be organized and managed with multi-criteria decision analysis (MCDA) techniques if taking several partly conflicting criteria into account (Malczewski and Rinner 2015). GIS and MCDA are commonly combined (GIS-MCDA) and often used during the recent years (Malczewski and Rinner 2015). MCDA with Saaty's (1997) analytic hierarchy process (AHP) has been demonstrated to be useful in the site selection of grid-connected solar power plant projects (Arán Carrión et al. 2008). MCDA combined with ordered weighted averaging (OWA) is even more powerful decisionmaking tool (Yager 1988; Boroushaki and Malczewski 2008). OWA includes into the calculations how many of the criteria should be accomplished to reach a satisfactory level of all criteria (Yager 1988). Combined method of AHP_OWA is an effective tool in decision-making because it is more flexible than AHP alone (Boroushaki and Malczewski 2008). AHP alone is a robust method (Charabi and Gastli 2011; Jamali et al. 2014) and OWA allows the user to define the amount of acceptable uncertainty in the process (Malczewski 2006). By utilizing spatial information and by recognizing the consequences of PV power plants, governmental decision-making and site selection can be supported and the loss of cultural heritage, ecosystem services, biodiversity, and whole ecosystems can be avoided.

AHP_OWA has been used in multiple cases of MCDA (Hokkanen and Salminen 1997; Bell et al. 2011; Joerin et al. 2001; Drobnik et al. 2017). AHP is commonly used to solve multi criteria problems of renewable energy (Chatzimouratidis and Pilavachi 2009; Sánchez-Lozano et al. 2013; Uyan 2013; Watson and Hudson 2015), but only a few articles include OWA as part of MCDA method of solar power plants site selection (Charabi and Gastli 2011). In addition, social effects are poorly represented in these studies. Social factors such as aesthetics (Yonca Aydin et al. 2010) and landscape values (Bergmann et al. 2006; Chiabrando et al. 2011; Molina-Ruiz et al. 2011; Pasqualetti 2011) are sometimes included in the MCDA processes. Wide MCDA studies include social factors of renewable energy such as job creation (Kosenius and Ollikainen 2013; Ahmad and Tahar 2014), public acceptance 
88 (Wüstenhagen et al. 2007; Amer and Daim 2011; Ahmad and Tahar 2014), and distances to historical sites and cities (Sánchez-Lozano et al. 2013; Watson and Hudson 2015).

90 On one hand, studies are focused on numerous factors of energy efficiency and solar energy potential as well as on economical facts (Charabi and Gastli 2011), but on the other hand, multiple surveys of renewable energy attitudes exist (Krohn and Damborg 1999; Kaldellis 2005; Sardianou and Genoudi 2013; Ek and Persson 2014; Olson-Hazbourn et al. 2016; among others). Nevertheless, according to our knowledge, surveys have not been applied in GIS environment together with physical and environmental factors of solar power plants.

The present study identifies optimal areas for PV solar energy projects, along with multiple aspects of sustainable energy, including social factors in a form of survey results as GIS layers. Three aspects, solar energy potential, environmental facts, and social characteristics were considered. Suitable locations for PV solar energy projects were determined using spatial information of northern Chile. AHP_OWA was used in the MCDA process to resolve the most suitable areas. Finally, the individual result layers were combined by using weighted summing.

\section{MATERIAL AND METHODS}

101

2.1.

Study area

Study area includes four regions of Northern Chile (Fig. 1): Arica and Parinacota (XIV), Tarapacá (I), Antofagasta (II), and Atacama (III). These regions receive scarce precipitation mainly in the Andes and as coastal fogs in the coast (Moreira-Muñoz 2011). Opposite to the coastal area, inland has the world's driest desert, the Atacama Desert. Vegetation in the study area varies from non-vegetated true deserts to grasslands and scrubs, and contains small areas of forests (Pliscoff and Luebert 2006). Cities are mainly in the coastal area or situated close to mines. Agricultural land can be found in river valleys where water is available. 


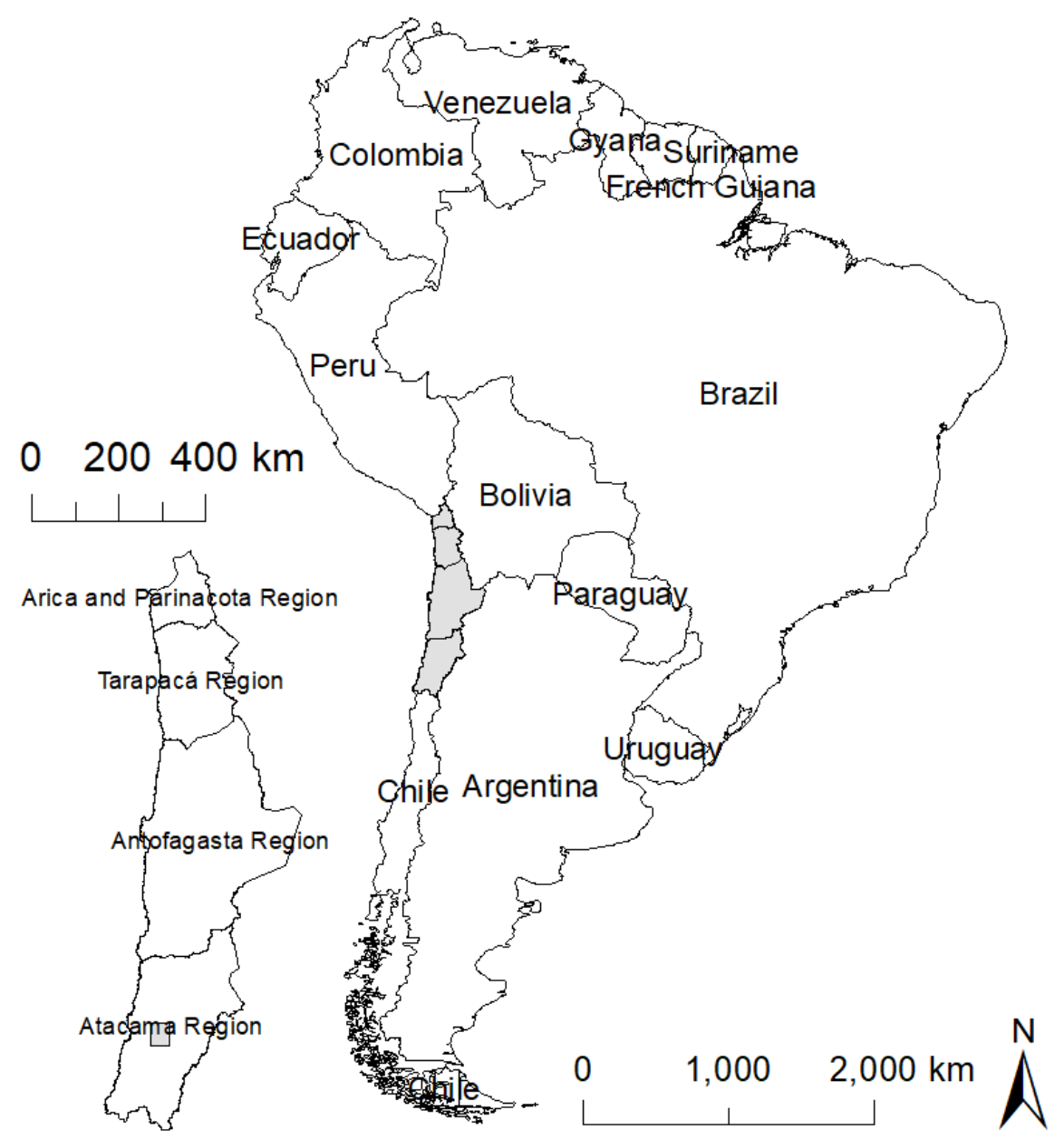

Fig. 1. Chile is on the Pacific Ocean side of South America shown on the right. Study area is situated on four regions shown with grey color in the main map and enlarged on the left. Focus area used in sensitivity analysis is indicated with grey color in Atacama region shown in the regional map at bottom left.

\subsection{Methods}

Site selection of PV plants was carried out using the multi-criteria decision-support system. The study had one goal: Locate optimal sites for PV plants in northern Chile considering social and environmental aspects of sustainable development. The goal was reached through three objectives: 1 . Determine high solar energy potential sites with economically reasonable distances to roads and power lines. 2. Exclude areas of conservation and/or high biodiversity from optimal sites and prevent vegetation loss. 3. Consider the social impacts and find socially acceptable sites. Downloadable georeferenced data were used to analyze the three objectives. In addition, a survey was used in decision-making to characterize the chosen social aspects given below. Pretreatment of the georeferenced data was done with ArcGIS ${ }^{\circledR}$ v10.1. (ESRI, Redlands, CA) and all MCDA-related data analyzes were performed with TerrSet ${ }^{\circledR}$ v18.20. 
Objectives were characterized through three criteria: physical, environmental, and social (Table 1). Criteria were divided into factors (Table 1). Physical criteria were divided into 5 continuous factors: Average temperature (temperature hereafter), global irradiation, orography (i.e. slope and orientation), distance to power lines, and highway accessibility (i.e. distance to power lines). Environmental factors were divided into 2 continuous factors (biomass, vegetation type rarity), and one categorical factor (land use). Social factors were divided into two continuous factors (distance from the closest city and biomass), and one categorical factor (visibility from the roads) (see reasoning for the factors: "Defining decision rules").

Constraints of the site selection were defined with binary values, 0 as non-suitable site and 1 as suitable (Table 2). Environmental factors had several constraints including protected terrestrial and aquatic sites (Table 2). Social aspects had two constraints: visibility from historical sites and from typical zones. Typical zones were areas including cultural environment and traditional landscapes that are categorized as valuable to conserve by the Ministry of Public Education of Chile (2010). No solar power plants were allowed to be visible inside the 10-km radius from historical sites or typical zones. The continuous and categorical factors are given in Table 1 and the constraints in Table 2.

Continuous factors were standardized directly with fuzzy sets, by converting them into value range 0-255 (Table 1), because using 8-bit (one byte) values makes the MCE calculations in TerrSet faster (Eastman 2015). In our case, value 0 indicates the least suitable and 255 the most suitable locations. Fuzzy sets are functions that change the values from non-membership to membership class smoothly so that sharp boundaries are not created (Eastman 2016). Categorized factors were given relative importance values (Jamali et al. 2014) with expert judgement, before they were standardized with fuzzy sets (Table 1). Land use classes were given values from 1 to 4 according to the lands' former introduction to anthropogenic use (Table 1). When giving the weights to land use anthropogenic affected sites (i.e. urbanized, cultivated, and mosaics) were weighted to be more suitable areas than sites at their natural state (i.e. shrubs, herbaceous coverage, and forests). Visibility was given values either 1 or 2 according to 10-km radius (Table 1). Afterwards all factor levels were compared pair-wise and relative importance weights (RIWs) were calculated (Saaty 1997) (Table 3, Fig. 2). OWA-method (Yager 1988; Boroushaki and Malczewski 2008) was applied to all three aspects (environmental, social, and physical) (Table 4, Fig. 2). The final map was calculated with equal AHP-weights (0.333) and with weighted linear combination (WLC) to combine the conflicting suitability maps of criteria to find the best sites (Table 5, Fig. 2). Equal weights and WLC was used to obtain equality between the three aspects, because WLC aloud free tradeoff between the aspects. Each one of the aspects reaching high suitability values at certain pixel can be fully tradeoff with another aspect in 
WLC. Therefore, the optimal areas of all tree aspects can be presented equally in a final map. Finally, a sensitivity analysis was done by performing factor removal (Malczewski and Rinner 2015). All factors were first given equal weights and then one factor at a time were taken off from the analysis to see the effect of that single factor, and to enable the calculation of change in the amount of suitable areas (Malczewski and Rinner 2015).

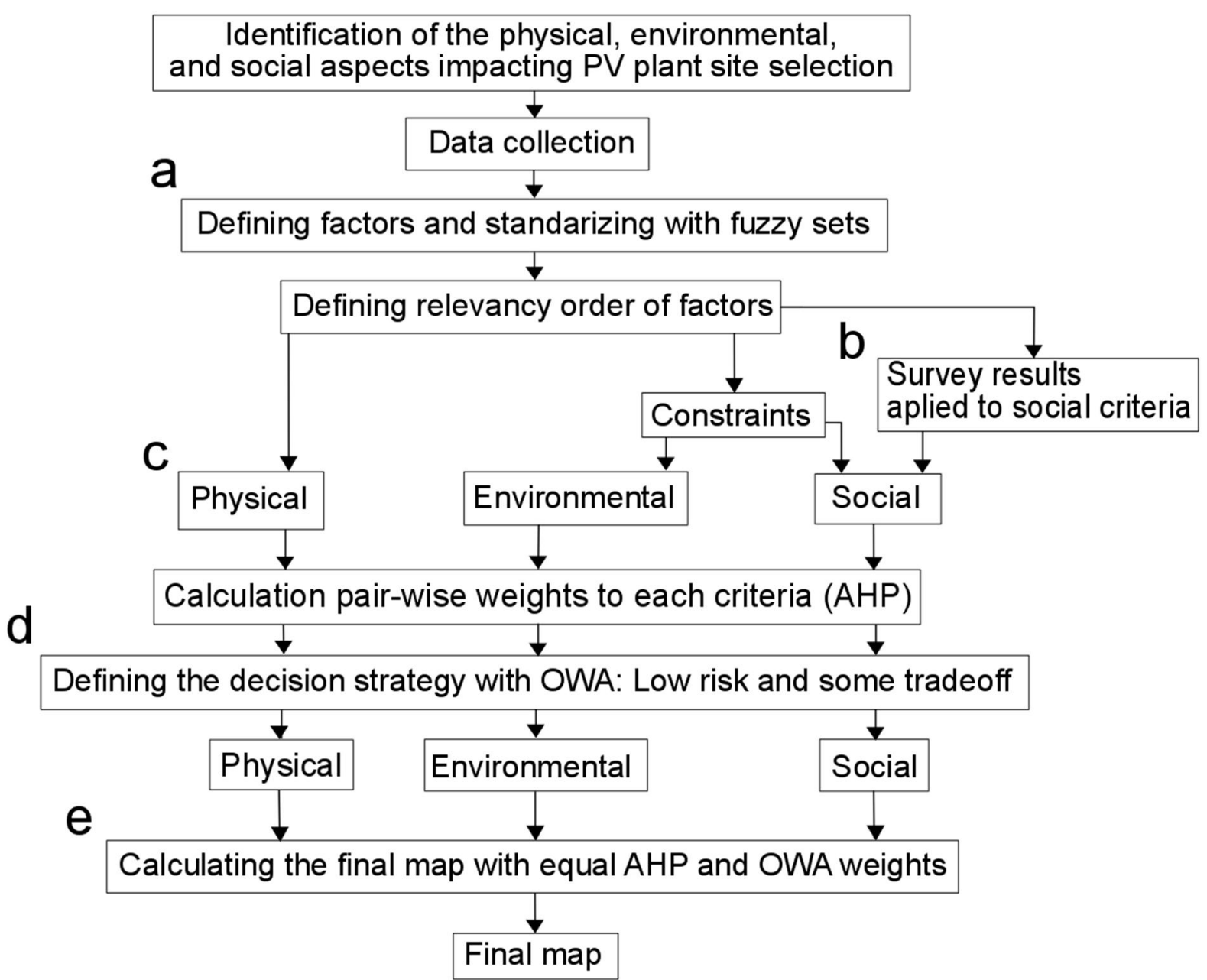

Fig. 2. Work flow for location optimization of PV solar power plants. After identification and collection of the data, a) factors were standardized with fuzzy sets and their relevancy order was evaluated, then b) environmental and social constraints were defined and survey of social factors where applied to define the AHP weights of social factors. Next, c) physical and environmental factors were given AHP values according to literature and expert judgement. After AHP weighting, d) factors were given to tradeoff with OWA -method. For the final map, e) equal AHP and OWA weights were used. 
Table 1. Criteria and categorical factors used in the AHP_OWA method. Mo. stands for "monotonically".

\begin{tabular}{|c|c|c|c|c|c|c|}
\hline \multirow{2}{*}{$\begin{array}{l}\text { Criteria } \\
\text { Physical }\end{array}$} & \multirow[t]{2}{*}{ Factor } & \multicolumn{2}{|c|}{ Fuzzy membership (Eastman 2015) } & \multirow[t]{2}{*}{ Class range / description } & \multirow{2}{*}{$\begin{array}{l}\text { Motivation } \\
\text { To all physical factors: }\end{array}$} & \multirow[t]{2}{*}{ Source (Additional information) } \\
\hline & & Function & Shape & & & \\
\hline & Slope & Sigmoidal & Mo. Decreasing & $0-90^{\circ}$ & $\begin{array}{l}\text { Arán-Carrión et al. } \\
\text { (2008) }\end{array}$ & $\begin{array}{l}\text { ASTER GLOBAL DEM (2011), } \\
\text { (Under } 3 \% \text { suitable) }\end{array}$ \\
\hline & Orientation & Sigmoidal & Symmetric & $0-359^{\circ}$ & & $\begin{array}{l}\text { ASTER GLOBAL DEM (2011), } \\
\text { North most suitable. }\end{array}$ \\
\hline & Global irradiation & Sigmoidal & Mo. Increasing & $3.9-7.8 \mathrm{kWh} / \mathrm{m}^{2} /$ day & & $\begin{array}{l}\text { Ministry of Energy, Chile (2013) } \\
\text { (years 2006-2010) }\end{array}$ \\
\hline & Temperature & Linear & Mo. Decreasing & $\left(-6^{\circ} \mathrm{C}\right)-18{ }^{\circ} \mathrm{C}$ & & $\begin{array}{l}\text { Albers (2012), (Average: years 2001- } \\
\text { 2012) }\end{array}$ \\
\hline & Highway access & J-shaped & Mo. Decreasing & $\begin{array}{l}0 \mathrm{~km}-4 \mathrm{~km}: \\
\mathrm{a}=2 \mathrm{~km} \text { and } \mathrm{b}=4 \mathrm{~km}\end{array}$ & & Albers (2012) \\
\hline & Distance to grid & J-shaped & Mo. Decreasing & $\begin{array}{l}0 \mathrm{~km}-5 \mathrm{~km}: \\
\mathrm{a}=2.5 \mathrm{~km} \text { and } \mathrm{b}=5 \mathrm{~km}\end{array}$ & & $\begin{array}{l}\text { National Power System Coordinator, } \\
\text { Chile (2016) (SIC and SING) }\end{array}$ \\
\hline \multicolumn{7}{|c|}{ Environmental } \\
\hline & Biomass (NDVI) & Sigmoidal & Mo. Decreasing & $(-1)-0.2$ & Pettorelli et al. (2005) & $\begin{array}{l}\text { Landsat } 5 \text { TM, (August-December } \\
\text { 2011) }\end{array}$ \\
\hline & Vegetation type rarity & user defined & Mo. Increasing & $1434-4197000$ ha & $\begin{array}{l}\text { Margules and Pressey } \\
(2000)\end{array}$ & $\begin{array}{l}\text { Pliscoff and Luebert (2006); } \\
\text { SINiA }_{\text {BETA }}(2016)\end{array}$ \\
\hline & Land use & Sigmoidal & Mo. Decreasing & $\begin{array}{l}\text { Bare soil 1, } \\
\text { Agricultural/urbanized 2, } \\
\text { Mosaics*3, Natural } \\
\text { vegetation** } 4\end{array}$ & Expert judgement & Albers (2012) \\
\hline \multicolumn{7}{|l|}{ Social } \\
\hline & $\begin{array}{l}\text { Distance from cities > } \\
5000 \text { inhabitants }\end{array}$ & J-shaped & Mo. Increasing & $0-10 \mathrm{~km}$ & $\begin{array}{l}\text { Arán-Carrión et al. } \\
\text { (2008) }\end{array}$ & SINIAbeta \\
\hline & Landscape*** & Sigmoidal & Mo. Decreasing & Non-visible 1 , Visible 2 & $\begin{array}{l}\text { SEIA (2003); Molina- } \\
\text { Ruiz et al. (2011) }\end{array}$ & $\begin{array}{l}\text { ASTER GLOBAL DEM (2011); } \\
\text { Albers (2012); SINIAbeta, }\end{array}$ \\
\hline
\end{tabular}

165 *Mosaic A: Crops-Shrubs-grasslands/ Mosaic B: Crops-Forest-other natural vegetation

$166 * *$ Broadleaf forest, deciduous, closed/ Broadleaf forest, evergreen/ Cover with herbaceous/ Shrubs regularly waterlogged/ Shrub cover, closed-open, deciduous/ Herbaceous

167 coverage, closed-open/ Low coverage with herbaceous shrubs/ Ice, snow

$168 * * *$ Landscape value seen from roads within a $10-\mathrm{km}$ radius. 
170 Table 2. Constraints of environmental and social factors.

\begin{tabular}{ll}
\hline $\begin{array}{l}\text { Environmental } \\
\text { Water }\end{array}$ & \\
\hline & Wetlands \\
& Ramsar classified wetlands (2012) \\
& Protected aquifers XIV-II \\
Terrestrial & National parks \\
& Natural sanctuaries \\
& Priority areas to biodiversity \\
& Nationally conserved assets \\
& National reserves \\
& Conserved private areas \\
& Strategical regions for protection of biodiversity \\
& UNESCO bio reserve \\
& No visible PV solar plants within 10-km radius \\
from typical zones and historical monuments.
\end{tabular}


172 Table 3. Pair-wise comparisons and AHP weights of the three criteria

\begin{tabular}{|c|c|c|c|c|c|c|c|}
\hline Physical* & Temperature & $\begin{array}{c}\text { Global } \\
\text { irradiation }\end{array}$ & Slope & Orientation & $\begin{array}{l}\text { Distance to } \\
\text { Roads }\end{array}$ & $\begin{array}{l}\text { Distance to } \\
\text { SIG or SING }\end{array}$ & Weights \\
\hline Temperature & 1 & & & & & & 0.3825 \\
\hline Global irradiation & $1 / 2$ & 1 & & & & & 0.2504 \\
\hline Slope & $1 / 3$ & $1 / 2$ & 1 & & & & 0.1596 \\
\hline Orientation & $1 / 4$ & $1 / 3$ & $1 / 2$ & 1 & & & 0.1006 \\
\hline High way access & $1 / 5$ & $1 / 4$ & $1 / 3$ & $1 / 2$ & 1 & & 0.0641 \\
\hline Distance to SIG or SING & $1 / 6$ & $1 / 5$ & $1 / 4$ & $1 / 3$ & $1 / 2$ & 1 & 0.0428 \\
\hline Environmental** & Land use & NDVI & $\begin{array}{l}\text { Vegetation } \\
\text { type rarity }\end{array}$ & & & & \\
\hline Land use & 1 & & & & & & 0.5397 \\
\hline NDVI & $1 / 2$ & 1 & & & & & 0.2969 \\
\hline Vegetation type rarity & $1 / 3$ & $1 / 2$ & 1 & & & & 0.1633 \\
\hline Social** & $\begin{array}{c}\text { Distance from } \\
\text { the cities }\end{array}$ & $\begin{array}{l}\text { Landscape } \\
\text { value }\end{array}$ & $\begin{array}{c}\text { Vegetation } \\
\text { value (NDVI) }\end{array}$ & & & & \\
\hline Distance from the cities & 1 & & & & & & 0.5397 \\
\hline Landscape value & $1 / 2$ & 1 & & & & & 0.2969 \\
\hline Vegetation value (NDVI) & $1 / 3$ & $1 / 2$ & 1 & & & & 0.1633 \\
\hline
\end{tabular}


Table 4. Low risk and some tradeoff consisting OWA weights.

175

\begin{tabular}{lccccccr}
\hline & $1^{\text {st }}$ & $2^{\text {nd }}$ & $3^{\text {rd }}$ & $4^{\text {th }}$ & $5^{\text {th }}$ & $6^{\text {th }}$ & Equals to \\
\hline Physical & 0.500 & 0.300 & 0.125 & 0.050 & 0.025 & 0.000 & 1.000 \\
Environmental & 0.500 & 0.300 & 0.120 & 0.080 & & & 1.000 \\
Social & 0.500 & 0.300 & 0.200 & & & & 1.000 \\
\hline
\end{tabular}

Table 5. Equal AHP weights of the final map. WLC have the same values for $1^{\text {st }}, 2^{\text {nd }}$, and $3^{\text {th }}$ place which are the same as AHP values (0.3333).

\begin{tabular}{lcccr}
\hline Map with equal weights & Physical & Environmental & Social & Weights \\
\hline Physical & 1 & & & 0.3333 \\
Environmental & 1 & 1 & & 0.3333 \\
Social & 1 & 1 & 1 & 0.3333 \\
\hline
\end{tabular}

2.3. Defining decision rules

$$
\text { 2.3.1. Rules for physical criteria }
$$

Solar energy potential maps have already been created in Chile (Escobar et al. 2014; Ministry of Energy, Chile 2013). Despite of the importance of environmental and social criteria to sustainable site selection, physical solar energy potential still is the prime criterion. If sufficient solar energy potential is not reached, the installation of a new panel area is not reasonable (Boroushaki and Malczewski 2008). Physical factors were given importance weights in the following order: temperature, global irradiation, orography (slope, then orientation), highway accessibility and distance to power lines (Arán Carrión et al. 2008). Distance to power lines is not considered important, because the present study considers multiple purposes of local PV plant projects, which are not necessarily grid connected. Nevertheless, close distance to power lines gives an opportunity to connect the solar plant to grid when desired. Given the high potential of solar energy in northern Chile, risk of getting insufficient amount of solar radiation is small. Therefore, some tradeoff between the physical factor and intermediate risk with OWA weights was used.

\subsubsection{Rules for environmental criteria}

Considering the environmental criteria, water and vegetation are scarce in northern Chile. Therefore, they are the most important environmental factors and they were given $100 \mathrm{~m}$ buffer area to protect them. This distance was chosen based on Arán-Carrión et al. (2008). Areas with high biodiversity like national parks, private protected areas, nationally protected wetlands, etc. were considered as constraints (Table 2). Because environmental aspects are also closely related to social aspects (Liu et al. 2007), conserving water bodies, natural parks, and biodiversity 
may also maintain the welfare of the people and protect their sources of livelihood. Therefore, the constraints in the present study included also social characteristics.

Other considered environmental factors were intensity of land use, biomass, and vegetation type rarity. Land use was considered to have the highest weight and biomass the second highest (Table 2). In fact, agricultural fields have the highest biomass values in the study area, but they do not necessarily possess high endemic biodiversity. On the other hand, agricultural land has a high value for human wellbeing. Therefore, land use was given the highest value. Vegetation type rarity was important because desert vegetation may be scarce, and therefore, not always characterized properly by the amount of biomass. Some tradeoff between environmental factors was allowed in OWA because the factors could compensate each other to some extent. For example, high biomass areas could be sacrificed if the current land use was agriculture.

\subsection{3. $\quad$ Rules for social criteria}

Landscape around historical monuments and culturally important zones (i.e. typical zones) were ruled out from site selection by constraints because those areas possess a high cultural heritage. Visibility from the roads was given less value for suitability, if landscape value (i.e. active volcanos, hills with slope over $15 \%$ steep, high biodiversity sites, etc.) was expected to exist. According to Molina-Ruiz et al. (2011) 10-km visibility radius has the strongest visual impact to the viewer and, therefore, this constraint was chosen to the present study.

Social impact is known to be higher depending on how many people are affected by renewable energy installations (Fernandez Jimenez et al. 2015). More people will be affected by the visual effects of PV plants if they are seen from the cities than if they are seen from the roads. Therefore, highest weight was given to distance from the cities -factor and then visibility from the roads. If solar power plants would be right outside the city, social impacts would be strong. For example, movability from and in the city, would be affected because people must go around the power plant area (Tolli et al. 2006). Social factors were allowed to tradeoff (OWA) because of the uncertainty of the concern-based factors. Social factors decision rules were defined through distances from cities, 10-km radius non-visibility from the historical sites and typical zones, and applications from survey as described below.

\subsection{Spatial referenced data}

\subsubsection{Obtaining data}

Shapefiles of Chile such as regions, roads, vegetation, temperature, cities, and thematic maps (Tables 2 and 3) were downloaded from the webpages: IDE (2016), SINiABETA (2016) and Albers (2012). Landscape values and environmental regulations were obtained from SEIA (2013). Two power line systems, found in northern Chile, 
Central Interconnected System and Interconnected System of Norte Grande were obtained as point shapefiles from the National Power System Coordinator, Chile (2016). Landsat 5 Thematic Mapper (2011) images were downloaded from the U.S. Geological survey (USGS). The most accurate data, such as DEM and Landsat 5 TM (2011), had a resolution of 30 x 30 m. Global irradiation data was 500 x 500 m (Ministry of Energy, Chile 2013), and temperature had the lowest resolution of $4000 \times 4000 \mathrm{~m}$ (Albers 2012). Global irradiation data did not contain the region Arica and Parinacota, and parts of mountainous regions. Global irradiation data were filled with less accurate data where the Weather Research and Forecasting model (WRF) was used from the same source. Raster data (elevation and satellite pictures) were downloaded from USGS. ASTER GLOBAL DEM with 1 arc second resolution was used to calculate slope and orientation. All data were converted into raster format for the analyzes using a raster size of $60 \times 60 \mathrm{~m}$ (Fig. 3 a).

\subsubsection{Application of physical criteria}

Missing global irradiation data in Parinacota and Arica was filled with lower quality irradiation data (WRF, Ministry of Energy, Chile 2013) (Fig. 3 b). Both Global irradiation and temperature data were interpolated with kriging method using trend removal with second (global irradiation) and third (temperature) order polynomial surfaces. DEM was converted from angular to linear metric units (resampled to $60 \mathrm{x} 60 \mathrm{~m}$ ). Two additional distance layers were created indicating the distances from each raster cell center to the closest road and to the closest power line. These distances were obtained by converting raster cell locations into points and by performing spatial joining of roads and power lines to them (Fig. $3 \mathrm{c}$ ). DEM was also used to create slope and orientation data (Fig. 3 d).

\subsubsection{Application of environmental criteria}

Vegetation type rarity was calculated from Pliscoff and Lueberts' (2006) 40 vegetation zones found in the study area. One big ecosystem is better for the organisms than several small ones although the total surface area would be of the same size (Margules and Pressey 2000). Therefore, different vegetation types were given a numeric value by dividing the total surface area of the vegetation type with the amount of separate areas of certain vegetation type (Fig. 3 a). Vegetation zones with small surface areas were given lower suitability values than large vegetation zones. Land use was given values as described above (Fig. 3 a)

Rain falls to the Atacama Desert depending on El Niño Southern Oscillation (ENSO) (Troup 1965; Rasmusson and Wallace 1983; Vargas et al. 2000). It is an irregular oscillation in the Pacific Ocean, which changes wind and water temperatures. "El Niño" phenomenon brings warmer waters to the coast and more evaporation, which can 
lead to rains over the Atacama Desert (Aceituno and Montecinos 1993; Vargas et al. 2000; Houston 2006). Rain falls typically between May and August (Aceituno and Montecinos 1993; Muñoz-Schick et al. 2001; Houston 2006) and vegetation starts to bloom one month after the rain (Vidiella et al. 1999). Year 2011 was a typical "El Niño" year and, therefore, Landsat 5 TM data from August to November 2011 was used (Fig. 3 e). Landsat 5 Thematic Mapper was used to calculate normalized difference vegetation index (NDVI) (Rouse et al. 1974) (Fig 3 e). While mosaicking, NDVI maps resolution was set to $60 \times 60 \mathrm{~m}$.

\subsubsection{Application of social criteria}

Survey (Fig. $3 \mathrm{f}$ ) included concerns of possible environmental impacts of PV solar power plants and it was performed during 2014-2015 in Chile. Survey had 444 participants including professionals and students of engineering (14\%) and environmentalist (22\%). Survey was given to the students at four different universities and spread through professional networks of engineers and environmentalist. Also non-professional people were randomly asked to participate to the survey in several towns from Iquique to Concepción (64\%). Engineers were working or studying electronics, civil engineering, mechanics, etc. and the environmentalists were biologists, agronomists, geographers, or environmental or forestry engineers. Questions were answered using a Likert's scale. Public acceptance with scale: $1=\mathrm{I}$ haven't thought about it, $2=$ Not concerned at all, $3=$ Little concerned, $4=$ Quite concerned, 5 = Very concerned (Fig. 4). Explorative factor analysis (Thurstone 1935) was performed to group the questions. Cronbach's alpha (Cronbach 1951) was calculated before and after doing the factor analysis, and the factor analysis grouping of variables was accepted if the alpha was improved or maintained the same value. For the higher concern areas, smaller suitability values were given. Three most important potential concerns in the survey were considered as important concerns (Fig. 4): loss of flora and fauna, loss of scenic landscape, and increase of groundwater uptake for the cleaning of the panels. AHP weights were given in the order presented above and in Table 3.

Concerns over loss of flora and fauna were included into the study by preferring low biodiversity areas. Therefore, NDVI layer was used again in this context, as "vegetation value", but values were recalculated using the weights of social factors. In addition, human health is associated with ecosystems health (Tzoulas et al. 2007), and ecosystem services affect positively to human well-being (MEA 2005). Landscape was also considered important to be maintained and that was included in the visibility considerations. Since $10 \mathrm{~km}$ is considered as high visibility impact area (Molina-Ruiz et al. 2011), landscape values from the roads were considered with the same visibility radius, and were determined using the Viewshed tool of ArcGIS (Fig. 3 f). Visibility results from the roads, cities, and historical and natural monuments were calculated with ArcGIS Viewshed tool using digital elevation data 
95

(DEM). Areas with potential mountain landscape value, where there was a slope of $15 \%$ or more and with an area of at least $500 \times 500 \mathrm{~m}$, were also defined, but it is not known if those areas are considered to have scenic value. Distances from these slopes were defined a $10-\mathrm{km}$ radius and extracted by masking the result with the visibility layer to find those hillsides which can be seen from the roads. Areas with high biodiversity, water bodies, protected areas, etc. were also included in the high visibility impact area. The visibility layer was edited manually, by clipping out the $10-\mathrm{km}$ radius buffer where landscape value targets were not found. Finally, to keep the social impacts small, proper distance for solar power plants from the large cities was defined to be over 5 km (Arán Carrión et al. 2008), and under the 5-km suitability decreased rapidly. Spatial joining was used to define the distances from the cities (Fig. 3 d).

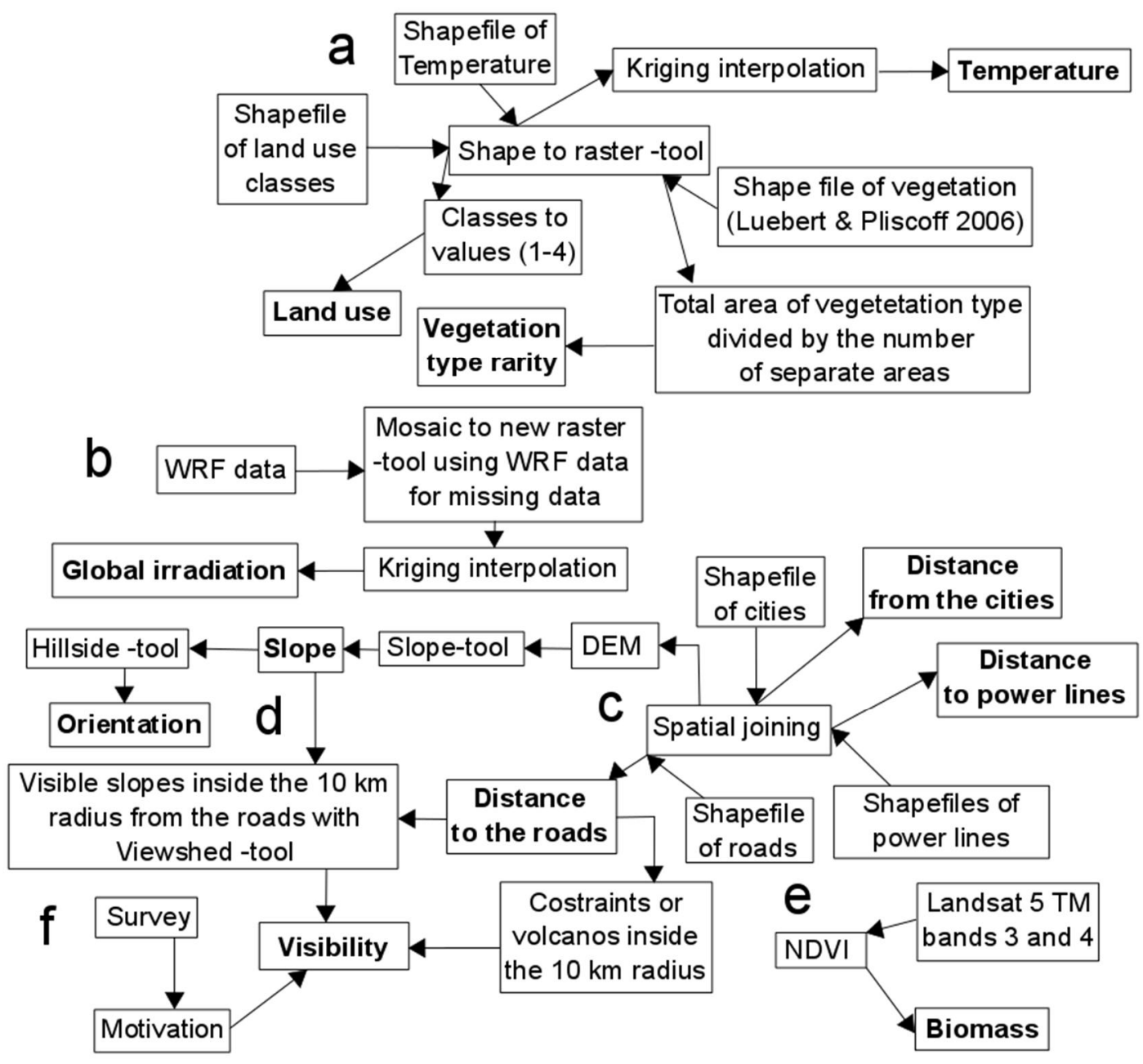

Fig. 3. Data modification of the factors: a) Shapefiles were converted to raster and given numerical values and survey gave the motivation for the landscape values, b) two global irradiation data were joined, c) distance to the roads and power lines, and distance from the cities were calculated with spatial joining using DEM cell center based points, d) slope and orientation were calculated from the DEM, e) biomass was calculated using NDVI, and 
f) shapefiles visibility layer was created identifying areas inside the $10 \mathrm{~km}$ from the roads containing landscape value. Created layers (i.e. factors) are indicated with bold letters.

\section{Concerns of potential impacts of solar power plants}

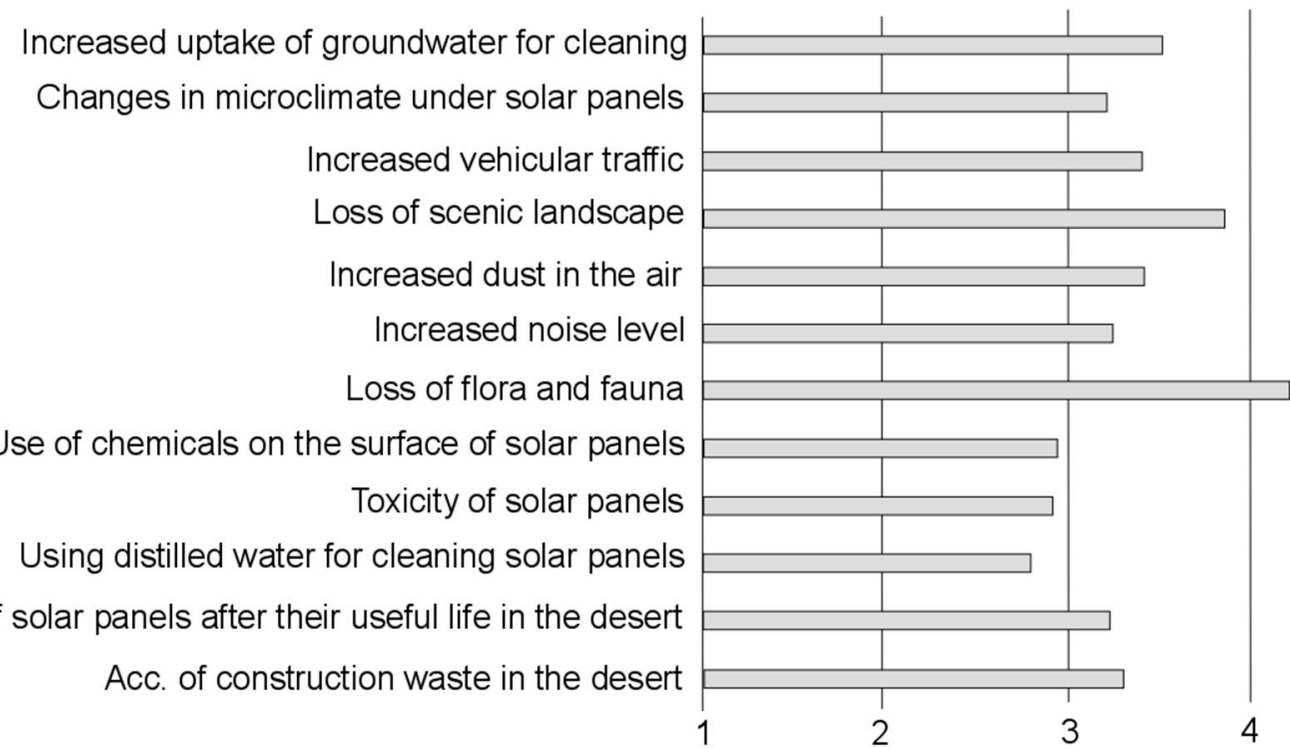

Fig. 4. Average concern answers of potential environmental impact of PV plants. Abbreviation Acc. stands for accumulation.

\section{RESULTS AND DISCUSSION}

Created map is an overall view of the larger area and cannot substitute environmental impact assessments of specific areas done with field work. Especially smaller important habitats of rare species cannot be found from low-resolution satellite images, and therefore, are not shown on the resulting map.

Used OWA-method, with low risk and some tradeoff, can be over cautious considering that solar energy potential is abundant in the whole study area. Therefore, the most suitable areas in the present study are highly suitable. Allowing more tradeoff between the factors would make the estimated suitability more uncertain. Map demonstrated large areas with high suitability for PV plant projects. Highest suitability areas were found alongside roads and power lines in Antofagasta region. In addition, suitability grew higher towards the Andes in Atacama region (Fig. 5). In fact, absolute desert in the central valley in Antofagasta, Tarapacá, and Arica and Parinacota areas are highly suitable for solar power plant projects. In Atacama region, Andean area is more suitable than the coastal region (Fig. 5) because of high biodiversity values and lower solar radiation potential of the coast. 
319 Conflicting to high suitability at the Andes, mountainous areas were also defined having a high landscape value 320 (Fig. 5).

321 Solar radiation is one of highest in the world in the study area (Corral et al. 2012; Jiménez-Estévez et al. 2015; Salazar et al. 2015). Nevertheless, suitability in the central valley is decreased by temperature (Fig. 5). Elevated temperatures lower the energy efficiency of solar panels (Dubey et al. 2013). For example, reduction of temperature by $3-9{ }^{\circ} \mathrm{C}$, the electrical performance improves so that the same amount of energy can be produced with $2 \mathrm{~m}^{2}$ smaller panel surface area (Dubey et al. 2013). Therefore, even the lowest values of global irradiation, $3.89 \mathrm{kWh} / \mathrm{m}^{2} /$ day, can be suitable for solar power plant projects if temperatures are lower. The Atacama Desert in northern Chile has one of the highest solar radiation potential in the world (Corral et al. 2012; Jiménez-Estévez et al. 2015; Salazar et al. 2015). Solar irradiation of northern Chile is between $3.89-7.80 \mathrm{kWh} / \mathrm{m}^{2} /$ day, while similar studies reported 3.89 - 5.56 kWh / m² / day in Turkey (Uyan 2013) and 4.56 - 4.91 in Spain (Arán Carrión et al. 2008). Therefore, the Atacama Desert is an ideal location to install solar energy if only the solar energy potential is considered.

Even though the solar energy potential is high in some remote places, they are not reasonable places for installations, if there is no energy-demanding infrastructure nearby. However, these places can be attractive to local mines, which are abundant in the Andean region. Lowest priority was given to the distance to power lines and roads, but they are also clearly seen as higher score areas because other factors are high in those areas as well. According to Gottschamer and Zhang (2016) environmental, technological, societal, policies, and economic factors should all be considered in RES projects, because they are all connected. In the present study, connection between social and environmental factors were clearly seen. Landscape values and amount of biomass had characteristics that were categorized in environmental and in social aspects. In contrast, survey results were not straightforward to interpret. Yonca Aydin et al. (2010) concluded that because solar energy is seen as clean energy, some people see renewable energy installations as positive. Nevertheless, other people might reject them. In the present study, people who rejected PV solar plant installations can also be more concerned of possible environmental or social impacts. Nevertheless, concerns gained by the survey, corresponded with the landscape values determined by SEIA (2003) national guide of environmental impact assessment. Watson and Hudson 2015; among others), the method used here gave less suitability values to vegetated areas because vegetation is included as an index and because it has both cultural and environmental values. Areas with 
348 possible landscape value are also defined here. For example, many mountainous roadsides show lower suitability 349 (Fig. 5). Map predicts possible landscape value areas, which should be confirmed in the field. In fact, it is not 350 known if these areas contain aesthetic values because of the physical area described above in application of social 351 factors.

352 Absolute desert in the central valley from Arica and Parinacota to the northern part of Atacama region shows high suitability values also due to the land use and low NDVI values (Fig. 5). The coastal area, especially in Atacama region, shows low suitability values (Fig. 5). Coastal areas have fogs, which bring humidity to them, and therefore, possess higher amounts of biomass. Fogs decrease solar energy potential received by the ground and lower suitability further (Fig. 5). Cultivated areas have monocultures of grapes, but they do possess endemic vegetation as well. Nevertheless, they have higher suitability for PV plant projects than the surrounding mountains, because cultivated areas are highly modified compared to natural sites (Fig. 5). 

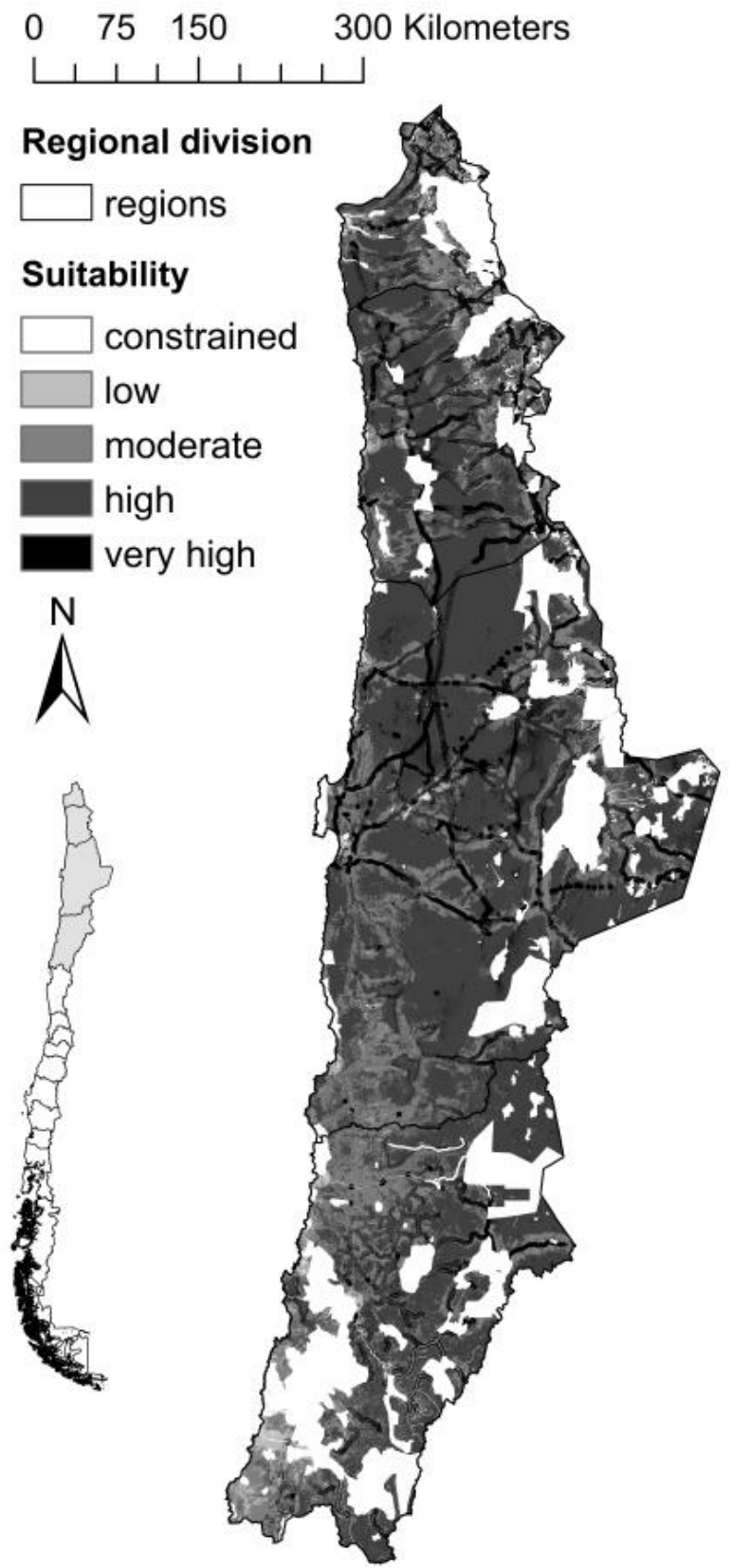

Fig. 5. Final map including physical, environmental, and social aspects of optimal site selection. Natural breaks were used to classify the suitability areas into five classes given in the legend in ArcGIS.

Sensitivity analysis

Sensitivity analyses were conducted for all factors, and in each of them one factor was removed (Fig. 6). Removal of factors slope, distance to roads, and distance to power lines, increased the area of very high suitability (Table 6) indicating that these factors defined where the very high suitability areas are (Fig. 6 d, f, g, j and 1). Therefore, they are highly important qualities when creating suitability map for PV solar power plants. Removal of temperature, global irradiation, or biomass caused low suitability area to increase, while high suitability classes 
a)
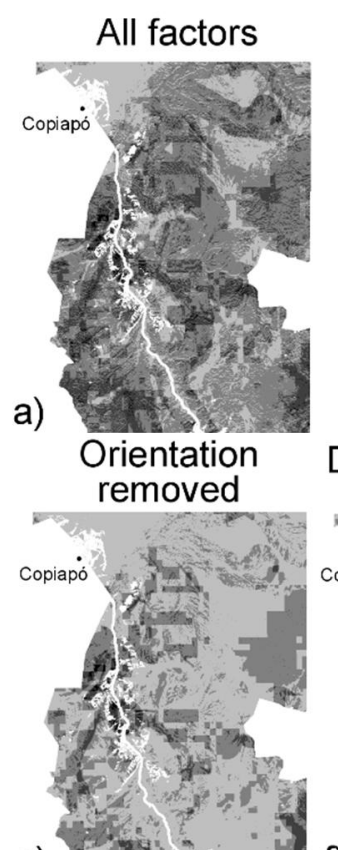

e)

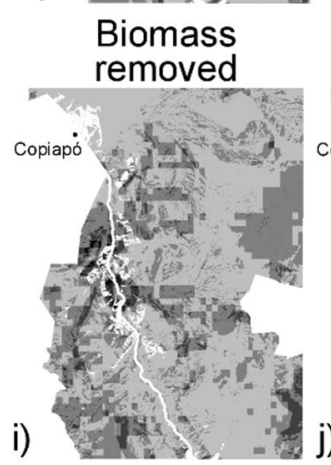

\section{Physical} factors

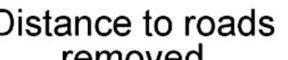
removed
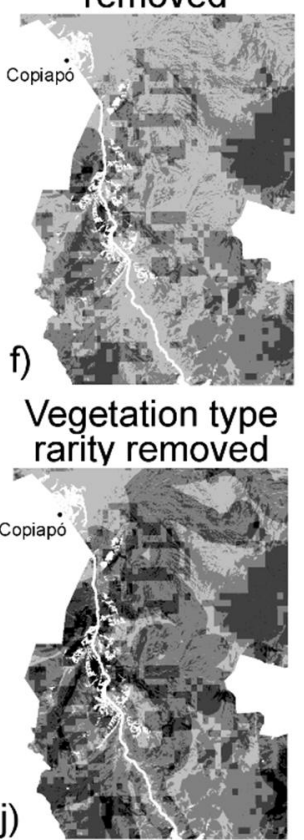

b)

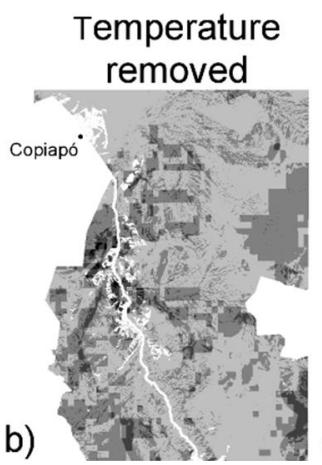

Distance to power

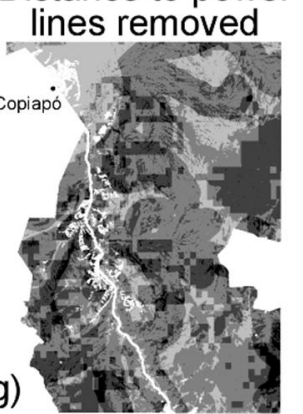

)
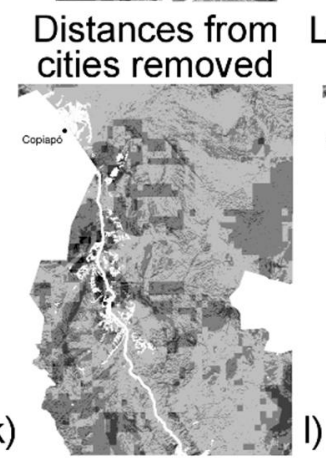

c)

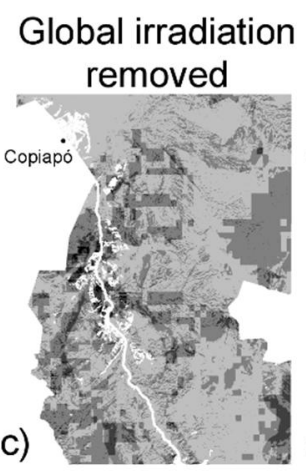

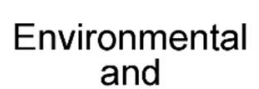

social factors

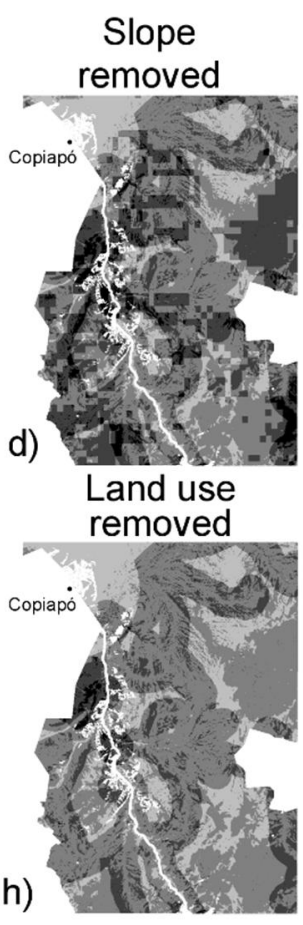

Landscape values removed

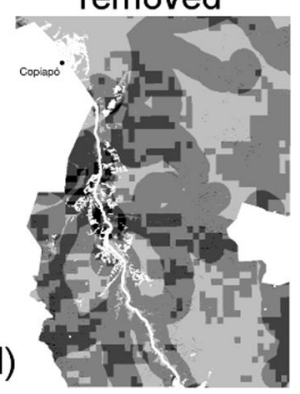

$N$

\section{Suitability}

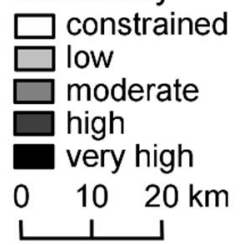

Fig. 6. Suitability maps showing changes caused by factor removal method. First map was obtained with a) all factors and equal weights, and then b)-1) show results obtained by removal of each factor. The maps are showing the focus area, Valley of Copiapó in the Atacama region. Constraint on the left side of focus area is "desierto florido" and on the right middle "Quebrada de Serna". River Copiapó with 50 meters buffer runs from the South East to the North West direction. Natural breaks method in ArcGIS was used to classify suitability. 
Table 6. Factor removal sensitivity analysis showing changes caused by individual factors calculated as percentages compared to equally weighted all-factors-included situation.

\begin{tabular}{|c|c|c|c|c|c|c|c|c|}
\hline \multirow[b]{2}{*}{ Factor removed } & \multicolumn{2}{|c|}{ Low } & \multicolumn{2}{|c|}{ Moderate } & \multicolumn{2}{|c|}{ High } & \multicolumn{2}{|c|}{ Very high } \\
\hline & $\mathrm{km}^{2}$ & $\%$ & $\mathrm{~km}^{2}$ & $\%$ & $\mathrm{~km}^{2}$ & $\%$ & $\mathrm{~km}^{2}$ & $\%$ \\
\hline Temperature & 13428 & 16 & -1870 & -2 & -10535 & -12 & -1031 & -1 \\
\hline Solar radiation & 11595 & 13 & -1093 & -1 & -9544 & -11 & -964 & -1 \\
\hline Slope & -4532 & -5 & -7112 & -8 & -3920 & -5 & 15570 & 18 \\
\hline Orientation & 8972 & 10 & -738 & -1 & -7498 & -9 & -779 & -1 \\
\hline Distance to roads & -951 & -1 & -6237 & -7 & -5775 & -7 & 12943 & 15 \\
\hline $\begin{array}{l}\text { Distance to power } \\
\text { lines }\end{array}$ & -4474 & -5 & -7013 & -8 & -3777 & -4 & 15270 & 18 \\
\hline Land use & -85 & 0 & 4540 & 5 & -4284 & -5 & -167 & 0 \\
\hline Biomass (NDVI) & 11508 & 13 & -1721 & -2 & -8830 & -10 & -958 & -1 \\
\hline $\begin{array}{l}\text { Vegetation type } \\
\text { rarity }\end{array}$ & -4025 & -5 & -2273 & -3 & 3658 & 4 & 2648 & 3 \\
\hline Distance to cities & 8090 & 9 & -1006 & -1 & -6361 & -7 & -770 & -1 \\
\hline Landscape value & 5213 & 6 & -722 & -1 & -4690 & -5 & 221 & 0 \\
\hline
\end{tabular}

Combined AHP_OWA method applied here was found useful for preplanning of PV plant projects in northern detailed information is encouraged. Method presented here, can be applied in any region of the world when planning PV power plant locations if the same kind of data is available for the site. Method is most suitable to deserts because water and natural vegetation were used as constraints.

Social impacts and locals' opinions should be included in the decision-making processes. Nevertheless, care should be taken when evaluating social factors and displaying them on a map, because opinions are hard to interpret. In fact, opinions differ among people and overall opinions can include conflicts. In addition, cultural and environmental aspects are not always separable into two distinct categories of factors. Including social aspects to PV solar plants site selection planning, conflicting sites, such as high energy potential areas with high vegetation, can be detected. Therefore, possible conflicts between human welfare and solar energy projects can be avoided. In the future, if available data exists, lands of the indigenous peoples should be added to spatial decision-making studies. 


\section{Acknowledgments}

The authors thank Cristian Orellana Urbina, Nelson Jara Arriagada y Pablo Espinoza Astudillo for collecting the survey answers, and Eduardo Soto Sepúlveda for his ideas. Funding for the study was supplied by the Academy of Finland (grant no 269468).

\section{1}

2

\section{REFERENCES}

Aceituno P, Montecinos A (1993) Análisis de la estabilidad de la relación entre la oscilación del sur y la precipitación en América del sur. Bull Inst Fr Études Andines 22 (1):53-63.

Ahmad S, Tahar RM (2014) Selection of renewable energy sources for sustainable development of electricity generation system using analytic hierarchy process: A case of Malaysia. Renew Energ 63:458-466.

Albers C (2012) Coberturas SIG para la enseñanza de la Geografía en Chile. Universidad de La Frontera. Temuco. Retrieved in 2016 from www.rulamahue.cl/mapoteca.

Alsema EA (2000). Energy Pay-back Time and CO2 Emissions of PV Systems. Prog photovoltaics: Research and Applications 8:17-25.

Amer M, Daim TU (2011) Selection of renewable energy technologies for a developing county: A case of Pakistan. Energy for Sustainable Development 15:420-435.

Antrop M (2005) Why landscapes of the past are important for the future. Landscape Urban Plan 70:21-34.

Arán Carrión J, Espín Estrella A, Aznar Dols F, Zamorano Toro M, Rodríguez M, Ramos Ridao A (2008) Environmental decision-support systems for evaluating the carrying capacity of land areas: Optimal site selection for grid-connected photovoltaic power plants. Renew Sust Energ Rev 12:2358-2380.

ASTER (Advanced Spaceborne Thermal Emission and Reflection Radiometer) (2016) Retrieved in 2016 from https://earthexplorer.usgs.gov/ ASTER GDEM is a product of NASA and METI.

Bell ML, Hobbs BF, Elliot EM, Ellis H, Robinson Z. (2011) An evaluation of multicriteria methods in integrated assessment of climate policy. Journal of Multi-Criteria Decision Analysis 10:229-256.

Bergmann A, Hanleyb N, Wright R (2006) Valuing the attributes of renewable energy investments. Energ Policy 34:1004-1014. 
Binder CR, Hinkel J, Bots PWG, Pahl-Wostl C (2013) Comparison of Frameworks for Analyzing Socialecological Systems. Ecology and Society 18(4):26.

Boroushaki S, Malczewski J (2008) Implementing an extension of the analytical hierarchy process using ordered weighted averaging operators with fuzzy quantifiers in ArcGIS. Comput Geosciences 34:399-410.

Carver SJ (1991) Integrating multi-criteria evaluation with geographical information systems. Int J Geogr Inf Syst $5(3): 321-339$.

Charabi Y, Gastli A (2011) PV site suitability analysis using GIS-based spatial fuzzy multi-criteria evaluation. Renew Energ 36:2554-2561.

Chatzimouratidis AI, Pilavachi PA (2009) Technological, economic and sustainability evaluation of power plants using the Analytic Hierarchy Process. Energ Policy 37:778-787.

Chiabrando R, Fabrizio E, Garnero G (2011) On the applicability of the visual impact assessment OAISPP tool to photovoltaic plants. Renew Sust Energ Rev 15:845-850.

Corral N, Anrique N, Fernandes D, Parrado C, Cáceres G (2012) Power, placement and LEC evaluation to install CSP plants in northern Chile. Renew Sust Energ Rev 16:6678-6685.

Cronbach LJ (1951) Coefficient alpha and the internal structure of tests. Psychometrica 16:297-334.

Daniel TC (2001) Whither scenic beauty? Visual landscape quality assessment in the $21^{\text {st }}$ century. Landscape Urban Plan 54:267-281.

Drobnik T, Huber R, Grêt-Regamey A (2017) Coupling a settlement growth model with an agro-economic land allocation model for securing ecosystem services provision. J Environ Plann Man 60(7): 1127-1152.

Dubey S, Sarvaiya JN, Seshadri B, 2013. Temperature Dependent Photovoltaic (PV) Efficiency and Its Effect on PV Production in the World a Review. Energy Procedia 33:311-321.

Eastman JR (2015) TerrSet tutorial. Clark University 1987-2015. www.clarklabs.org

Eastman JR (2016) TerrSet manual. Clark University 1987-2016. www.clarklabs.org

Ek K, Persson L (2014) Wind farms - Where and how to place them? A choice experiment approach to measure consumer preferences for characteristics of wind farm establishments in Sweden. Ecol Econ 105:193-203. 
El Sistema de Evaluación de Impacto Ambiental (SEIA) (2003) Guia de Evaluacion de Impacto Ambiental - Valor $\begin{array}{llllll}\text { Paisajístico en } & \text { el } & \text { SEIA. } & \text { Retrieved } & \text { in } & 2016\end{array}$ from http://www.sea.gob.cl/sites/default/files/migration_files/guias/Guia_Evaluacion_Paisaje_130926.pdf

Escobar R, Cortés C, Pino A, Bueno Pereira E, Ramos Martins F, Cardemil JM (2014) Solar energy resource assessment in Chile: Satellite estimation and ground station measurements. Renew Energ 71:324-332.

Fernandez Jimenez A, Mendoza-Villena M, Zorzano-Santa MP, Garcia-Garrido E, Lara-Santillan P, ZorzanoAlba E, Falces A (2015) Site selection for new PV power plants based on their observability. Renew Energ 78:715.

Gottschamer L, Zhang Q (2016) Interactions of factors impacting implementation and sustainability of renewable energy sourced electricity. Renew Sust Energ Rev 65:164-174.

Hokkanen J, Salminen P. (1997) Locating a waste treatment facility by multicriteria analysis. Journal of MultiCriteria Decision Analysis 6:175-184.

Hosenuzzaman M, Rahim NA, Selvaraj J, Hasanuzzaman M, Malek ABMA, Nahar A (2015) Global prospects, progress, policies, and environmental impact of solar photovoltaic power generation. Renew Sust Energ Rev 41:284-297.

Houston J (2006) Variability of precipitation in the Atacama Desert: Its causes and hydrological impact. Int J Climatol 26:2181-2198.

Infrastructura de Datos Geospatiales (IDE) (2016) Retrieved in 2016 from http://www.ide.cl/descarga/capas.html. Jamali IA, Mörtberg U, Olofsson B, Shafique M (2014) A Spatial Multi-Criteria Analysis Approach for Locating Suitable Sites for Construction of Subsurface Dams in Northern Pakistan. Water Resour Manage 28:5157-5174. Jiménez-Estévez G, Palma-Behnke R, Latorre R, Morán L (2015) Heat and Dust - The Solar Energy Challenge in Chile. IEEE Power \& Energy Magazine 3(2):71-77.

Joerin F, Theriault M, Musy A. (2001) Using GIS and outranking multicriteria analysis for land-use suitability assessment. Int. J. Geogr. Inf. Sci 15(2):153-174.

Johansen JRS, Clair LL (1986) Cryptogamic soil crusts: recovery from grazing near camp Floyd State Park, Utah, USA. Great Basin Nat 46:632-640.

Kaldellis JK (2005) Social attitude towards wind energy applications in Greece. Energ Policy 33:595-602. 
Kosenius AK, Ollikainen M (2013) Valuation of environmental and societal trade-offs of renewable energy sources. Energ Policy 62:1148-1156.

Krohn S, Damborg S (1999) On Public Attitudes Towards Wind Power. Renew Energ 16:954-960.

Landsat 5 Thematic Mapper (2011) Retrieved in 2016 from https://earthexplorer.usgs.gov/ courtesy of the U.S. Geological Survey.

Liu J, Dietz T, Carpenter SR, Alberti M, Folke C, Alberti M, Redman CL, Schneider SH, Ostrom E, Pell AN, Lubchenco J, Taylor WW, Ouyang Z, Deadman P, Kratz T, Provencher W (2007) Coupled human and natural systems. Ambio 36(8):639-649.

Malczewski J (1999) GIS and multicriteria decision analysis. New York: JohnWiley \& Sons, Inc.

Malczewski J (2006) Ordered weighted averaging with fuzzy quantifiers: GIS-based multicriteria evaluation for land-use suitability analysis. International Journal of Applied Earth Observation and Geoinformation 8:270-277.

Malczewski J, Rinner C (2015) Multicriteria Decision Analysis in Geographic Information Science. In: Balram S, Dragicevic S (eds.) Burnaby, Canada. Springer New York Heidelberg Dordrecht London. pp. 1-331

Margules CR, Pressey RL (2000) Systematic conservation planning. Nature 405:243-253.

Millennium Ecosystem Assessment (MEA) (2005) Ecosystems and Human Well-being: Synthesis. Island Press, Washington, DC.

Retrieved

in

2016 from http://www.millenniumassessment.org/documents/document.356.aspx.pd

Ministry of Energy, Chile (2013) retrieved in 2016 from http://ernc.dgf.uchile.cl/Explorador/Solar2/info/SIG/ Ministry of Public Education, Chile (2012) Law n ${ }^{\circ} 17.288$, Legisla sobre monumentos nacionales; modifica las leyes 16.617 y 16.719; deroga el decreto ley 651, de 17 de octubre de 1925. Latest version 2012. Retrieved in 2017 from file://C:/Users/annasuur/Downloads/LEY-17288_04-FEB-1970.pdf

Molina-Ruiz J, Martínez-Sánchez JM, Pérez-Sirvent C, Tudela-Serrano ML, García Lorenzo ML (2011) Developing and applying a GIS-assisted approach to evaluate visual impact in wind farms. Renew Energ 36:11251132.

Moreira-Muñoz A (2011) Current Climate and Vegetation. In: Werger M.J.A. (ed.), Plant geography of Chile. Springer, Dordrecht, Heidelberg, London, New York, pp. 33-34. 
Moriarty P, Honnery D (2012) What is the global potential for renewable energy? Renew Sust Energ Rev 16:244252.

Muñoz-Schick M, Pinto R, Mesa A, Moreira-Muñoz A (2001) "Oasis de neblina" en los cerros costeros del sur de Iquique, region de Tarapacá, Chile, durante el evento El Niño 1997-1998. Rev Chil Hist Nat 74:389-405.

National Power System Coordinator, Chile (2016) SIC retrieved in 2016 from https://sic.coordinadorelectrico.cl/sobre-sic/sic/ and SING from http://cdec2.cdecsing.cl/pls/portal/cdec.pck_web_cdec_pages.pagina?p_id=2.

Nguyen KQ (2007) Wind energy in Vietnam: resource assessment, development status and future implications. Energ Policy 35:1405-13.

Olson-Hazbourn SK, Krannich RS, Robertson PG (2016) Public views on renewable energy in the Rocky Mountain region of the United States: Distinct attitudes, exposure, and other key predictors of wind energy. Energy Research \& Social Science 21:1-179.

Omer AM (2008) Green energies and the environment. Renew Sust Energ Rev 12:1789-821.

Parsons R, Daniel TC (2002) Good looking: in defense of scenic landscape aesthetics. Landscape Urban Plan 60:43-56.

Pasqualetti MJ (2011) Social barriers to renewable energy landscapes. Geogr Rev 101(2):201-223.

Pettorelli N, Vik JO, Mysterud A, Gaillard JM, Tucker CJ, Stenseth NC (2005) Using the satellite-derived NDVI to assess ecological responses to environmental change. Trends Ecol Evol 21(1):11.

Pliscoff P, Luebert F (2006) Sinopsis bioclimática y vegetacional de Chile, frist ed. Editorial Universitaria.

Ramsar Chile (2012). The Ramsar Convention. Retrieved in 2016 from http://www.ramsar.org/wetland/chile.

Rasmusson EM, Wallace JM (1983) Meteorological Aspects of the El Niño/Southern Oscillation. Science 222:1195-1202.

Rouse JW, Haas RH, Scheel JA, Deering DW (1974) Monitoring Vegetation Systems in the Great Plains with ERTS. Proceedings, 3rd Earth Resource Technology Satellite (ERTS) Symposium 1:48-62.

Saaty T (1997) A Scaling method for priorities in hierarchical structures. J Math Psychol 15:234-81.

Salazar G, Checura Diaz MS, Denegri MJ, Tiba C (2015) Identification of potential areas to achieve stable energy production using the SWERA database: A case study of northern Chile. Renew Energ 77:208-216. 
Sánchez-Lozano JM, Teruel-Solano J, Soto-Elvira PL, García-Cascales MS (2013) Geographical Information Systems (GIS) and Multi-Criteria Decision Making (MCDM) methods for the evaluation of solar farms locations: Case study in south-eastern Spain. Renew Sust Energ Rev 24:544-556.

Sardianou E, Genoudi P (2013) Which factors affect the willingness of consumers to adopt renewable energies? Renew Energ 57:1-4.

Sevenant M, Antrop M (2009) Cognitive attributes and aesthetic preferences in assessment and differentiation of landscapes. J. Environ Manag 90:2889-2899.

Shafiee S, Topal E (2009) When will fossil fuel reserves be diminished? Energ Policy 37(1):181-9.

SiniabeTA, Environmental Ministery of Chile (MMA) (2016). Retrieved in 2016 from http://ide.mma.gob.cl/.

Suuronen A, Muñoz-Escobar C, Lensu A, Kuitunen M, Guajardo Celis N, Espinoza Astudillo P, Ferrú M, Taucare-Ríos A, Miranda M, Kukkonen JVK (2017) The Influence of Solar Power Plants on Microclimatic Conditions and the Biotic Community in Chilean Desert Environments. Environ Manage doi:10.1007/s00267017-0906-4

Thurstone LL (1935) The vectors of mind: Multiple-factor analysis for the isolation of primary traits. The University of Chicago Press.

Tolli M, Recanatesi F, Piccinno M, Leone A (2016) The assessment of aesthetic and perceptual aspects within environmental impact assessment of renewable energy projects in Italy. Environ Impact Asses 57:10-17.

Troup AJ (1965) The ‘southern oscillation'. Q J Roy Meteor Soc 14:490-506.

Tsoutsos T, Frantzeskakib N, Gekasb V (2005) Environmental impacts from the solar energy technologies. Energ Policy 33:289-296.

Tzoulas K, Korpela K, Venn S, Yli-Pelkonen V, Kaźmierczak A, Niemela J, James P (2007) Promoting ecosystem and human health in urban areas using Green Infrastructure: A literature review. Landscape Urban Plan 81(3):167-178.

United Nations (2015) 21st Conference of the Parties of the UNFCCC in Paris. Retrieved in 2017 from https://treaties.un.org/doc/Publication/UNTS/No\%20Volume/54113/Part/I-54113-0800000280458f37.pdf

Uyan M (2013) GIS-based solar farms site selection using analytic hierarchy process (AHP) in Karapinar region, Konya/Turkey. Renew Sust Energ Rev 28:11-17. 
555 Vargas G, Ortlieb L, Rutlant J (2000) Aluviones históricos en Antofagasta y su relación con eventos El 556 Niño/Oscilación del Sur. Rev geol Chile 27(2):157-176.

557 Vidiella PE, Armesto JJ, Gutiérrez JR (1999) Vegetation changes and sequential flowering after rain in the 558 southern Atacama Desert. J of Arid Environ 43:449-458.

559 Wang JJ, Jing YY, Zhang CF, Zhao JH (2009) Review on multi-criteria decision analysis aid in sustainable energy 560 decision making. Renew Sust Energ Rev 13:2263-2278.

561 Wang Q, Qiu HN (2009) Situation and outlook of solar energy utilization in Tibet, China. Renew Sust Energ Rev $562 \quad 13: 2181-2186$.

563 Watson JJW, Hudson MD (2015) Hudson Regional Scale wind farm and solar farm suitability assessment using 564 GIS-assisted multi-criteria evaluation. Landscape and Urban Plan 138:20-31.

565 Wu Z, Anping H, Chun C, Xiang H, Duoqi S, Zhifeng W (2014) Environmental impacts of large-scale CSP plants 566 in North-Western China. Environ Sci: Processes \& Impacts 16:2432-2441.

567 Wüstenhagen R, Wolsink M, Bürer MJ (2007) Social acceptance of renewable energy innovation: An introduction 568 to the concept. Energ Policy 35:2683-2691.

569 Yager RR (1988) On Ordered Weighted Averaging Aggregation Operators in Multicriteria Decisionmaking. IEEE $570 \quad$ T Syst Man Cyb 18:183-190.

571 Yonca Aydin N, Kentel E, Duzgun S (2010) GIS-based environmental assessment of wind energy systems for 572 spatial planning: A case study from Western Turkey. Renew Sust Energ Rev 14:364-373. 